\title{
Milk Composition and Milk Quality of Saanen Crossbreed Goats Supplemented by Mineral Blocks
}

\author{
M. F. Mohd Nora, N. D. Rusli ${ }^{a},{ }^{,}$, K. Mat ${ }^{a}$, C. H. Hasnita ${ }^{a}$, \& P. Mira ${ }^{b}$ \\ aDepartment of Agriculture Science, Faculty of Agro-Based Industry, University Malaysia Kelantan, \\ Jeli Campus, 17600 Jeli, Kelantan, Malaysia \\ ${ }^{\mathrm{b} S}$ chool of Biomedical Engineering and Health Sciences, Faculty of Engineering, Universiti Teknologi Malaysia, \\ 81310, Johor Bharu, Johor, Malaysia \\ *Corresponding author: nordini@umk.edu.my \\ (Received 19-09-2019; Revised 31-03-2020; Accepted 22-04-2020)
}

\begin{abstract}
The objective of this study was to investigate the effect of urea molasses multi-nutrient mineral block (UMMB) and medicated urea molasses multi-nutrient mineral block (MUMB) supplemented group on milk composition and milk quality of Saanen lactating does. A 90-day feed trial was conducted at a dairy goat farm in Felda Kemahang, Tanah Merah, Kelantan, Malaysia. Twenty four (24) Saanen lactating does (average milk yield $<1 \mathrm{~L} / \mathrm{d}$ ) were randomly assigned to four groups with six (6) goats each. Animals fed a basal diet, which consisted of $3 \mathbf{~ k g}$ Napier grass (Pennisetum purpureum) and $1 \mathrm{~kg}$ commercial goat pellet as a control group. The experimental groups received equal amounts of basal diet with supplementation of UMMB and MUMB which were formulated using local agriculture by-products; and commercial mineral block (CMB), respectively. Milk samples were collected every two weeks for the analyses of milk composition, i.e., protein, fat, lactose, total solids, density, freezing point, $\mathrm{pH}$, and temperature using EKOmilk analyzer. All results were analyzed using one-way ANOVA followed by Tukey's test by SPSS software version 23. It was found that milk yield in the group supplemented with UMMB $(1.52 \mathrm{~L} / \mathrm{d})$ was significantly higher $(\mathrm{p}<0.05)$, followed by MUMB $(1.31 \mathrm{~L} / \mathrm{d}), \mathrm{CMB}(0.96 \mathrm{~L} / \mathrm{d})$, and control $(0.78 \mathrm{~L} / \mathrm{d})$. Besides, the different group did not cause significant effect $(p>0.05)$ on milk composition and total bacteria count. Meanwhile, iron milk content in goat supplemented with MUMB $(1.46 \mathrm{mg} / \mathrm{g})$ was significantly lowered $(\mathrm{p}<0.05)$, approaching the optimum value $(0.36-0.75)$ compared to the control $(4.08 \mathrm{mg} / \mathrm{kg})$. In conclusion, UMMB and MUMB supplements had improved milk quality in terms of iron content and fatty acid concentration, which potentially can be utilized as feed supplements to increase the productivity of lactating goats.
\end{abstract}

Keywords: milk composition; Saanen goats; UMMB; MUMB

\section{INTRODUCTION}

Asia is the largest goat milk producer contributing $58.35 \%$ to the total milk produced in the world. Dairy goat and dairy sheep farming have a significant contribution to the national economy of Asia countries (Skapetas \& Bampidis, 2016). In Malaysia, the livestock sector contributes $12.2 \%$ of Malaysia Gross Domestic Product in the agriculture sector in 2018 (Department of Statistics, 2019). Dairy goat production in Malaysia is a small livestock sector with no local breed specifically for milk production. Since goat milk has a significant niche market, the development of dairy goat farming has increased with large importation of dairy goats from various countries. Sazila et al. (2018) reported that the young generation in Malaysia showed a higher intention in livestock farming compared to previous years. However, the data and information on the production and nutrition of dairy goats locally are very limited (Shahudin et al., 2018).

Ruminant livestock production is dependent on feeds comprising of fodder and crop residues. However, these feeds are of inferior qualities. To improve livestock production, the efficiency of feed nutrients utilization must be optimized through feed supplementation (Mengistu \& Hassen, 2018). In Malaysia, a major constraint of the dairy goat is nutrition deficiency and imbalance apart from poor animal health, which can severely decrease the productivity of dairy goat as well as decrease dairy goat's milk production and milk quality (Kanani et al., 2006).

Feeds and fodders available throughout the country are rather scarce. To overcome this problem, most local farmers still use goat concentrates extensively to feed their animals since the concentrates can be included in the diet at a range of 35\%-65\% (Tufarelli et al., 2009). However, as the main ingredient of concentrates is imported, the price of commodity fluctuates and increases every year. To reduce the production cost for feed and nutrients as well as for value addition of poor-quality feeds and fodders of ruminant animals, it is necessary to implement the supplementation strategy using local agriculture by-products. 
Urea molasses multi-nutrient block (UMMB) is a convenient and inexpensive method of providing a range of nutrients to animals. The UMMB can improve the digestion of low-quality roughages in the rumen as well as increase the utilization of crop residue (Mengistu \& Hassen, 2017). According to a previous study, the inclusion of $25 \%$ molasses, $30 \%$ brewers dried grains, $23 \%$ cottonseed cake, 5\% mineral salt, 5\% urea, and $12 \%$ cement as binders are the range used (Mubi et al., 2013). Another study came with the other different formulations as follows: $45 \%$ molasses, $3 \%$ urea, 13.25 $\%$ bran, $14 \%$ rice polish, $6 \%$ calcite, $4 \%$ calcium oxide, $4 \%$ magnesium oxide, $10 \%$ diammonium phosphate and $0.75 \%$ trace minerals (Muralidharan et al., 2016). However, UMMB with more quantities of non- sugar nutrients (within molasses) shows higher performance in live weight gain and feed conversion of the supplemented groups (Ramchurn \& Ruggoo, 2000).

Different compositions on the animal basal diet by increasing concentrate ratio in the goat feed did influence the milk yield and milk composition of goats (Min, 2005). Increasing the energy intake by changing the feed component will upsurge the average level of milk production near the animal's genetic potential. However, the addition of oil or fat in the diet increases the fatty acid component in the milk without affecting milk yield (Gómez-Cortés et al., 2018; Keles et al., 2017).

To our knowledge, no prior studies have investigated the UMMB supplementation in dairy goats in Malaysia. The UMMB and medicated urea molasses multi-nutrient block (MUMB) in the current study are newly developed using locally available feed resources, which serve as a complete supplement for ruminants. It was shown that UMMB and MUMB acted as an excellent source of non-protein nitrogen, energy, vitamin, and minerals for ruminant production (Mira et al., 2018). Therefore the current study aimed to investigate the effect of UMMB and MUMB supplemented group on milk composition and milk quality of Saanen lactating does.

\section{MATERIALS AND METHODS}

\section{Animals}

A 90-day feeding trial was done on a dairy goat farm in Felda Kemahang 1, Tanah Merah, Kelantan, Malaysia. Twenty-four female Saanen goats were assigned and allocated into four dietary treatments based on randomized complete block design with six goats per group. The animals' average weights were $40.58 \pm 1.50$ $\mathrm{kg}$ (mean $\pm \mathrm{SE}$ ). The goats were housed individually in wooden pens with a slatted floor two meters above the ground.

\section{Experimental Diet}

Animals were divided into four groups: a control group based on normal diet following farm practice (3 $\mathrm{kg}$ Napier grass and $1 \mathrm{~kg}$ concentrate), an experimental group with supplementation of UMMB; MUMB, and commercial mineral block (CMB) in the form of licks. Based on farm practice, all animals were fed based on forage to concentrate ratio of $75: 25$, consisted of $3 \mathrm{~kg}$ fresh Napier grass in the morning and $1 \mathrm{~kg}$ of concentrates in the afternoon. All experimental groups were fed isonitrogenous diets $(16 \% \mathrm{CP})$ for a period of 90 days and water was provided ad libitum.

\section{Preparation of UMMB and MUMB}

The ingredients of UMMB and MUMB utilized local agriculture by-product include rice bran, palm kernel cake (PKC), cornmeal, urea, molasses, and calcium oxide. MUMB contained $0.05 \%$ of fenbendazole for each $1 \mathrm{~kg}$ of blocks. After all the ingredients were mixed homogenously, the mixture poured into a wooden mold to form a preferable size. The final step was drying, which was commonly done under sunlight. After drying, the blocks were wrapped with polythene bags and stored in a dry condition. Each UMMB and MUMB were fed in the form of $2 \mathrm{~kg}$ block to the goats. Chemical compositions of UMMB, MUMB, CMB, as well as basal diets, were shown in Table 1 and 2 (Mira et al., 2018).

\section{Milk Collection}

Milk production was recorded daily for not less than six weeks during the morning milking. Similarly, milk samples were collected in the morning and pooled weekly. Individual milk samples were cooled to 5 to $8^{\circ} \mathrm{C}$ and transported in a thermo-box for laboratory analysis for milk composition.

\section{Chemical Analysis of Milk}

Protein, fat, lactose, total solid and density analyses. The milk samples were collected in a sterile bottle to reduce contamination for chemical analysis. About 100 $\mathrm{mL}$ of fresh milk sample was collected every two weeks for the analyses of protein, fat, lactose, total solid, density, freezing point, added water, $\mathrm{pH}$, and temperature using EKOmilk analyzer (BOND, EON Trading INC) at Veterinary Laboratory, Kota Bharu, Kelantan, Malaysia.

Milk mineral analysis. Minerals such as potassium $(\mathrm{K})$, sodium $(\mathrm{Na})$, magnesium $(\mathrm{Mg})$, Calcium (Ca), Manganese $(\mathrm{Mn})$, and ferum (Fe) were examined. Approximately $100 \mathrm{~mL}$ of milk samples were collected in a sterile bottle and were cooled under $-4^{\circ} \mathrm{C}$ in the freezer for storage. Then, these samples were analyzed using Atomic Absorption Spectroscopy (AAS) as described by Zailan \& Yaakub (2018).

Fatty acid analysis. Fatty acid profiling, including fat extraction in milk, was determined before and after the experiment. Approximately 100 samples per group were collected in a sterile bottle and were cooled under $-4^{\circ} \mathrm{C}$ in the freezer. The samples were analyzed using a gas chromatography-flame ionization detector (GC-FID) using IUPAC 2.301 method as described by Dieffenbacher \& Pocklinton (1987).

Microbiological analysis of milk. The microbiological test was conducted to investigate the microbial count 
Table 1. Chemical composition of supplements (Mira et al., 2018)

\begin{tabular}{lccr}
\hline \multirow{2}{*}{ Nutrients } & \multicolumn{3}{c}{ Supplements } \\
\cline { 2 - 4 } & UMMB & MUMB & CMB \\
\hline DM (\%) & 90.06 & 90.13 & 92.26 \\
Ash (\%) & 17.48 & 17.36 & 95.05 \\
OM (\%) & 82.52 & 82.64 & 4.95 \\
CP (\%) & 33.84 & 32.84 & ND \\
CF (\%) & 4.49 & 4.07 & ND \\
EE (\%) & 0.55 & 0.82 & ND \\
ADF (\%) & 5.47 & 5.45 & ND \\
NDF (\%) & 10.51 & 9.27 & ND \\
Ca (g/kg) & 36.54 & 34.95 & 21.23 \\
Cu (mg/kg) & 0.70 & 0.58 & 8.23 \\
Fe (mg/kg) & 11.27 & 3.87 & 259.07 \\
Zn (mg/kg) & 1.84 & 2.61 & 21.27 \\
\hline
\end{tabular}

Note: $\mathrm{UMMB}=$ Urea molasses multi-nutrient block; $\mathrm{MUMB}=$ Medicated urea molasses multi-nutrient block; $\mathrm{CMB}=\mathrm{Commercial}$ mineral block; $\mathrm{DM}=$ Dry matter; $\mathrm{OM}=$ Organic matter; $\mathrm{CP}=$ Crude protein $\mathrm{CF}=$ Crude fiber; $\mathrm{EE}=$ Ether extract; $\mathrm{ADF}=\mathrm{Acid}$ detergent fiber $\mathrm{NDF}=$ Neutral detergent fiber; $\mathrm{Ca}=$ Calcium; $\mathrm{Fe}=$ Ferum; $\mathrm{Cu}=$ Copper; $\mathrm{Zn}=\mathrm{Zinc} ; \mathrm{ND}=$ Not determined.

and bacterial presence before and after the experiment. The determination of milk quality was done using the standard plate count (SPC) method. A serial dilution of $10^{-2}, 10^{-3}, 10^{-4}, 10^{-5}$ was prepared by adding $1 \mathrm{~mL}$ of milk sample into $99 \mathrm{~mL}$ of Butterfield's Phosphate-Buffered Dilution Water (BPW) and then repeated by transferring $1 \mathrm{~mL}$ of the previous solution to $99 \mathrm{~mL}$ of diluent. All diluents were mixed and shaken 25 times within 7 seconds. One $\mathrm{mL}$ of each dilution was pipetted into the petri dishes which were appropriately marked. Next, 12 to $15 \mathrm{~mL}$ of plate count agar was added to each plate within 15 minutes of initial dilution. The sample dilution and agar medium were mixed thoroughly and uniformly by alternate rotation and back - and forth motion of plates. The agar was solidified and then inverted the solidified Petri dishes before they were incubated promptly for 48 hours at $35^{\circ} \mathrm{C}$.

\section{Statistical Analysis}

All results were analyzed using one-way ANOVA followed by Tukey's test by Statistical Package for the Social Science (SPSS) software version 23.
Table 2. Chemical composition of basal feed (Mira et al., 2018)

\begin{tabular}{lcc}
\hline \multirow{2}{*}{ Nutrients } & \multicolumn{2}{c}{ Basal feed } \\
\cline { 2 - 3 } & Napier grass & Goat pellet \\
\hline $\mathrm{DM}(\%)$ & 16.09 & 91.19 \\
Ash (\%) & 5.33 & 7.19 \\
$\mathrm{OM}(\%)$ & 94.67 & 92.81 \\
$\mathrm{CP}(\%)$ & 15.54 & 17.13 \\
$\mathrm{CF}(\%)$ & 33.26 & 20.07 \\
$\mathrm{EE}(\%)$ & 2.44 & 3.33 \\
$\mathrm{ADF}(\%)$ & 41.41 & 35.24 \\
$\mathrm{NDF}(\%)$ & 65.77 & 61.21 \\
$\mathrm{Ca}(\mathrm{g} / \mathrm{kg})$ & 0.40 & 3.86 \\
$\mathrm{Cu}(\mathrm{mg} / \mathrm{kg})$ & 4.46 & 0.97 \\
$\mathrm{Fe}(\mathrm{mg} / \mathrm{kg})$ & 10.69 & 45.18 \\
$\mathrm{Zn}(\mathrm{mg} / \mathrm{kg})$ & 1.83 & 0.25 \\
\hline
\end{tabular}

Note: $\mathrm{DM}=$ Dry matter; $\mathrm{OM}=$ Organic matter; $\mathrm{CP}=$ Crude protein; $\mathrm{CF}=$ Crude fiber; $\mathrm{EE}=\mathrm{Ether}$ extract; $\mathrm{ADF}=\mathrm{Acid}$ detergent fiber; $\mathrm{NDF}=$ Neutral detergent fiber; $\mathrm{Ca}=$ Calcium; $\mathrm{Fe}=$ Ferum; $\mathrm{Cu}=$ Copper; $\mathrm{Zn}=\mathrm{Zinc}$.

\section{RESULTS}

\section{Milk Composition of Saanen Goat's Milk}

The values of milk composition: temperature, fat, solid non-fat (SNF), density, protein, lactose (L), sucrose (S1), water, and freezing point (FP) are shown in Table 3 . There were no significant differences in milk composition between the treatment groups $(p>0.05)$ -

\section{Milk Mineral Contents}

Milk mineral contents between treatment groups were not significant $(p>0.05)$, except the iron content (Table 4). The optimal value of mineral content in goat milk was presented in Table 3 as a reference (Zamberlin et al., 2012). Most of the mineral contents in all groups were higher than the optimal volume except the potassium content.

\section{Standard Plate Count}

There were no significant differences $(p>0.05)$ of standard plate counts between groups (Table

Table 3. Milk composition of Saanen Crossbreed goats treated by urea molasses multi-nutrient block (UMMB), medicated urea molasses multi-nutrient block (MUMB), and commercial mineral block (Mean $\pm \mathrm{SE}$ )

\begin{tabular}{|c|c|c|c|c|c|c|c|}
\hline \multirow{2}{*}{$\begin{array}{l}\text { Treatment } \\
\text { groups }\end{array}$} & \multicolumn{7}{|c|}{ Composition } \\
\hline & $\begin{array}{c}\text { Temperature } \\
\left({ }^{\circ} \mathrm{C}\right)\end{array}$ & Fat (\%) & $\operatorname{Snf}(\%)$ & $\begin{array}{l}\text { Density } \\
\left(\mathrm{g} / \mathrm{cm}^{3}\right)\end{array}$ & Protein (\%) & $\mathrm{L}(\%)$ & F.P $\left({ }^{\circ} \mathrm{C}\right)$ \\
\hline Control & $27.85 \pm 0.38$ & $4.741 \pm 0.39$ & $8.31 \pm 0.58$ & $28.35 \pm 2.50$ & $2.99 \pm 0.22$ & $4.71 \pm 0.48$ & $-0.45 \pm 0.12$ \\
\hline $\mathrm{T} 1$ & $27.67 \pm 0.47$ & $4.25 \pm 0.31$ & $7.49 \pm 0.16$ & $25.58 \pm 0.60$ & $2.70 \pm 0.06$ & $4.12 \pm 0.13$ & $-0.48 \pm 0.01$ \\
\hline $\mathrm{T} 2$ & $27.71 \pm 0.45$ & $5.40 \pm 0.56$ & $7.94 \pm 0.15$ & $26.26 \pm 0.78$ & $2.85 \pm 0.06$ & $4.28 \pm 0.10$ & $-0.51 \pm 0.01$ \\
\hline $\mathrm{T} 3$ & $27.53 \pm 0.40$ & $4.33 \pm 0.33$ & $7.08 \pm 0.46$ & $23.83 \pm 1.59$ & $2.53 \pm 0.17$ & $4.07 \pm 0.13$ & $-0.47 \pm 0.01$ \\
\hline
\end{tabular}

Note: Control= Basal diet $(3 \mathrm{~kg}$ Napier grass and $1 \mathrm{~kg}$ concentrates $) ; \mathrm{T} 1=$ Basal diet+UMMB; $\mathrm{T} 2=$ Basal diet $+\mathrm{MUMB}$; $\mathrm{T} 3=\mathrm{Basal}$ diet $+\mathrm{CMB} ; \mathrm{Snf}=\mathrm{Solid}$ nonfat; L; Lactose; F.P= Freezing point. 
Table 4. Milk mineral contents of Saanen Crossbreed goats treated by urea molasses multi-nutrient block (UMMB), medicated urea molasses multi-nutrient block (MUMB), and commercial mineral block (Mean $\pm \mathrm{SE}$ )

\begin{tabular}{lccccc}
\hline \multicolumn{1}{c}{$\begin{array}{c}\text { Mineral contents } \\
(\mathrm{mg} / \mathrm{kg})\end{array}$} & Optimum value* & T1 & T2 & Treatments \\
\cline { 3 - 6 } & $1060-1920$ & $1275.7 \pm 401.98$ & $468.77 \pm 17.46$ & $1136.6 \pm 430.55$ & $478.6 \pm 41.71$ \\
Calcium & $0.36-0.75$ & $4.08 \pm 0.34^{\mathrm{c}}$ & $2.48 \pm 0.07^{\mathrm{bc}}$ & $1.46 \pm 0.05^{\mathrm{ab}}$ & $0 \pm 0.00^{\mathrm{a}}$ \\
Iron & $1350-2350$ & $1836.85 \pm 4.41$ & $1693.6 \pm 128.17$ & $1584.42 \pm 38.95$ & $1919.2 \pm 117.03$ \\
Potassium & $100-210$ & $206.52 \pm 5.19$ & $174.8 \pm 11.66$ & $3464.3 \pm 1893.79$ & $201.12 \pm 5.84$ \\
Magnesium & $340-500$ & $549.82 \pm 97.24$ & $874.35 \pm 102.16$ & $923.17 \pm 103.62$ & $745.57 \pm 118.86$ \\
Sodium & 0.05 & $0.22 \pm 0.11$ & $0.03 \pm 0.00$ & $0.03 \pm 0.02$ & $0.05 \pm 0.03$ \\
Manganese & & &
\end{tabular}

Note: *Source of Zamberlin et al. (2012). Means in the same column/row with different superscript differ significantly (p<0.05). Control= Basal diet (3 $\mathrm{kg}$ Napier grass and $1 \mathrm{~kg}$ concentrates); T1= Basal diet + UMMB; T2= Basal diet + MUMB; T3= Basal diet + commercial mineral block (CMB).

Table 5. Standard plate count (SPC) in raw milk of Saanen Crossbreed goats before and after treatment of urea molasses multi-nutrient block (UMMB), medicated urea molasses multi-nutrient block (MUMB), and commercial mineral block (Mean $\pm \mathrm{SE}$ )

\begin{tabular}{ccc}
\hline \multirow{2}{*}{$\begin{array}{c}\text { Treatment } \\
\text { groups }\end{array}$} & \multicolumn{2}{c}{$\begin{array}{c}\text { Standard plate count } \\
(\log \text { CFU/mL) }\end{array}$} \\
\cline { 2 - 3 } & Before & After \\
\hline Control group & $5.31 \pm 0.29$ & $5.75 \pm 0.07$ \\
T1 & $4.69 \pm 0.35$ & $5.50 \pm 0.17$ \\
T2 & $4.30 \pm 0.00$ & $5.81 \pm 0.09$ \\
T3 & $5.10 \pm 0.39$ & $5.66 \pm 0.14$ \\
\hline
\end{tabular}

Note: Control= Basal diet $(3 \mathrm{~kg}$ Napier grass and $1 \mathrm{~kg}$ concentrates); $1=$ Basal diet + UMMB; $\mathrm{T} 2=$ Basal diet + MUMB; $\mathrm{T} 3=$ Basal diet + commercial mineral block (CMB).

5). The SPC levels in the control group, UMMB, MUMB, and $\mathrm{CMB}$ before the supplementation were $5.31 \pm 0.29,4.69 \pm 0.35,4.30 \pm 0$ and $5.10 \pm 0.39$ respectively while the reading of SPC after the supplementation were $5.75 \pm 0.07,5.50 \pm 0.17,5.81 \pm 0.09$, and $5.66 \pm 0.14$, respectively.

\section{Fatty Acid Composition in Saanen Milk}

Total saturated fatty acid (SFA) and total unsaturated fatty acid (UFA) between treatment groups were not significant $(\mathrm{p}>0.05)$ (Table 6$)$. SFA value ( $\%$ in fat) in control, $\mathrm{UMMB}, \mathrm{MUMB}$, and $\mathrm{CMB}$ were $69.38 \pm 0.14$, $66.53 \pm 0.07,67.02 \pm 0.01$, and $69.88 \pm 0.06$, respectively, while for UFA, the value (\% in fat) in control, UMMB, MUMB, and CMB were 30.61 \pm 0.14 , 33.47 \pm 0.07 , $32.98 \pm 0.008$ and $30.12 \pm 0.06$ respectively. Table 6 shows that undecanoic acid (C11), lauric acid (C12), myristic acid (C14), pentadecanoic acid (C15) and palmitic acid $(\mathrm{C} 16)$ in $\mathrm{CMB}$ were significantly higher $(\mathrm{p}<0.05)$ compared to the other groups. However, butyric acid (C4), caproic acid (C6), caprylic acid (C8), capric acid (C10), undecanoic acid (C11), lauric acid (C12), tridecanoic acid (C13), myristic acid (C14), and pentadecanoic acid (C15) in UMMB and MUMB were significantly lowered $(p<0.05)$ compared to the other groups.

\section{DISCUSSION}

\section{Milk Composition of Saanen Goat's Milk}

When compared to the previous data reported by Strzałkowska et al. (2009), both protein and solid-nonfat percentages in this study were lower. Meanwhile, lactose, fat, density, and freezing point were higher. It was also reported previously that the values of protein, solid-non-fat, lactose, fat percentage, density, and freezing point were $3.12 \%, 8.34 \%, 4.42 \%, 3.85,1.025 \mathrm{~g} /$ $\mathrm{cm} 3$, and $-0.6{ }^{\circ} \mathrm{C}$, respectively (Strzalkowska et al., 2009). Although the UMMB and MUMB were high in protein and energy (Mira et al., 2018), the supplementations of UMMB and MUMB did not alter the milk composition significantly compared to the control group. Another study suggested that the stage of lactation of goats might affect milk composition of goat milk. Idowu \& Adewumi (2017) stated that milk composition of goat milk did change during the lactation period which was explained by another author as concentration effect, i.e., mineral content is low when the milk production is high and mineral content is high when the milk production is low (Currò et al., 2019).

\section{Milk Mineral Contents}

Based on the result, iron composition in milk in all dietary groups were exceeded the normal range, especially the control group. Following the UMMB and MUMB supplementations, the iron content in milk was significantly improved. The possible reason might be due to the high Napier grass intake in T1 and T2 (Mira et al., 2018). However, this reason was argued by Idamokoro et al. (2017) that pasture fodder did not affect iron concentration in milk. Iron binds naturally to the membrane of fat globules, casein, and whey protein, which are richly present in milk.

\section{Standard Plate Count}

For raw goat's milk, the limit value of the rolling geometric average of SPC was set at $6.18 \log$ CFU/ $\mathrm{mL}$ as according to Commission Regulation (EC) No 1662/2006 (Cupáková et al., 2012). Thus, the results of all treatments were under the limit and considered safe to be consumed. In contrast, the SPC level in all treatments 
Table 6. Fatty acid composition of Saanen Crossbreed goats treated by urea molasses multi-nutrient block (UMMB), medicated urea molasses multi-nutrient block (MUMB), and commercial mineral block (Mean $\pm \mathrm{SE}$ )

\begin{tabular}{|c|c|c|c|c|}
\hline \multirow{2}{*}{ Fatty acids (\% in fat) } & \multicolumn{4}{|c|}{ Treatment groups } \\
\hline & Control group & $\mathrm{T} 1$ & $\mathrm{~T} 2$ & $\mathrm{~T} 3$ \\
\hline $\mathrm{C} 4$ & $2.61 \pm 0.02^{\mathrm{b}}$ & $2.18 \pm 0.01^{\mathrm{a}}$ & $2.73 \pm 0.002^{\mathrm{b}}$ & $2.21 \pm 0.04^{\mathrm{a}}$ \\
\hline C6 & $2.48 \pm 0.01^{\mathrm{d}}$ & $1.90 \pm 0.01^{\mathrm{a}}$ & $2.25 \pm 0.004^{c}$ & $2.08 \pm 0.03^{b}$ \\
\hline $\mathrm{C} 8$ & $2.59 \pm 0.007^{c}$ & $1.93 \pm 0.007^{a}$ & $2.16 \pm 0.007^{b}$ & $2.18 \pm 0.02^{\mathrm{b}}$ \\
\hline $\mathrm{C} 10$ & $8.25 \pm 0.002^{c}$ & $6.44 \pm 0.001^{\mathrm{a}}$ & $6.37 \pm 0.001^{\mathrm{a}}$ & $7.53 \pm 0.04^{b}$ \\
\hline $\mathrm{C} 11$ & $0.00 \pm 0.00^{\mathrm{a}}$ & $0.00 \pm 0.00^{\mathrm{a}}$ & $0.00 \pm 0.00^{\mathrm{a}}$ & $0.07 \pm 0.0005^{b}$ \\
\hline $\mathrm{C} 12$ & $3.95 \pm 0.01^{c}$ & $3.83 \pm 0.007^{b}$ & $3.24 \pm 0.00^{\mathrm{a}}$ & $3.96 \pm 0.004^{c}$ \\
\hline $\mathrm{C} 13$ & $0.33 \pm 0.01^{\mathrm{b}}$ & $0.84 \pm 0.02^{\mathrm{d}}$ & $0.08 \pm 0.0005^{\mathrm{a}}$ & $0.63 \pm 0.002^{c}$ \\
\hline $\mathrm{C} 14$ & $9.29 \pm 0.03^{b}$ & $8.78 \pm 0.03^{a}$ & $8.84 \pm 0.009^{a}$ & $10.37 \pm 0.01^{c}$ \\
\hline $\mathrm{C} 15$ & $0.78 \pm 0.01^{\mathrm{a}}$ & $0.86 \pm 0.001^{b}$ & $0.75 \pm 0.004^{\mathrm{a}}$ & $0.97 \pm 0.00^{c}$ \\
\hline $\mathrm{C} 16$ & $25.55 \pm 0.11^{\mathrm{a}}$ & $26.56 \pm 0.04^{b}$ & $26.75 \pm 0.01^{b}$ & $28.20 \pm 0.07 \mathrm{c}$ \\
\hline $\mathrm{C} 17$ & $0.63 \pm 0.0005^{\mathrm{a}}$ & $0.67 \pm 0.007^{b}$ & $0.75 \pm 0.002^{c}$ & $0.63 \pm 0.001^{\mathrm{a}}$ \\
\hline $\mathrm{C} 18$ & $12.65 \pm 0.002^{c}$ & $12.20 \pm 0.04^{\mathrm{b}}$ & $12.80 \pm 0.01^{\mathrm{d}}$ & $10.72 \pm 0.006^{\mathrm{a}}$ \\
\hline $\mathrm{C} 20$ & $0.22 \pm 0.001^{\mathrm{a}}$ & $0.28 \pm 0.005^{b}$ & $0.24 \pm 0.01^{\mathrm{a}}$ & $0.26 \pm 0.004^{\mathrm{ab}}$ \\
\hline C14:1 & $0.12 \pm 0.001^{\mathrm{a}}$ & $0.16 \pm 0.002^{b}$ & $0.12 \pm 0.01^{\mathrm{a}}$ & $0.19 \pm 0.002^{\mathrm{b}}$ \\
\hline C15:1 & $0.19 \pm 0.003^{a}$ & $0.23 \pm 0.002^{b}$ & $0.19 \pm 0.00^{\mathrm{a}}$ & $0.22 \pm 0.002^{\mathrm{b}}$ \\
\hline C16:1 & $0.68 \pm 0.001^{\mathrm{a}}$ & $0.73 \pm 0.01^{\mathrm{a}}$ & $0.71 \pm 0.004^{\mathrm{a}}$ & $0.82 \pm 0.01^{b}$ \\
\hline C17:1 & $0.28 \pm 0.006^{b}$ & $0.26 \pm 0.00^{a}$ & $0.32 \pm 0.002^{c}$ & $0.26 \pm 0.0005^{\mathrm{ab}}$ \\
\hline $\mathrm{C} 18: \ln 9 \mathrm{c}$ & $26.24 \pm 0.02^{\mathrm{b}}$ & $27.85 \pm 0.03^{c}$ & $28.93 \pm 0.01^{\mathrm{d}}$ & $25.89 \pm 0.05^{\mathrm{a}}$ \\
\hline C18:2n6c & $2.38 \pm 0.10^{\mathrm{a}}$ & $3.61 \pm 0.09 \mathrm{~b}$ & $2.18 \pm 0.009^{a}$ & $2.27 \pm 0.02^{\mathrm{a}}$ \\
\hline C18:3n3 & $0.25 \pm 0.005^{\mathrm{a}}$ & $0.41 \pm 0.007^{b}$ & $0.26 \pm 0.02^{\mathrm{a}}$ & $0.27 \pm 0.00^{\mathrm{a}}$ \\
\hline C20:3n3 & $0.21 \pm 0.02^{\mathrm{ab}}$ & $0.18 \pm 0.001^{\mathrm{ab}}$ & $0.23 \pm 0.003^{b}$ & $0.16 \pm 0.002^{\mathrm{a}}$ \\
\hline C20:5n3 & $0.21 \pm 0.01^{b}$ & $0.00 \pm 0.00^{a}$ & $0.00 \pm 0.00^{\mathrm{a}}$ & $0.00 \pm 0.00^{\mathrm{a}}$ \\
\hline Total SFA & $69.38 \pm 0.14$ & $66.53 \pm 0.07$ & $67.02 \pm 0.01$ & $69.88 \pm 0.06$ \\
\hline Total UFA & $30.61 \pm 0.14$ & $33.47 \pm 0.07$ & $32.98 \pm 0.008$ & $30.12 \pm 0.06$ \\
\hline
\end{tabular}

Note: Means in the same column/row with different superscript differ significantly $(\mathrm{p}<0.05)$. Control= Basal diet $(3 \mathrm{~kg}$ Napier grass and $1 \mathrm{~kg}$ concentrates); T1= Basal diet + UMMB; T2= Basal diet + MUMB; T3= Basal diet + commercial mineral block $(\mathrm{CMB})$. SFA= saturated fatty acid, UFA= unsaturated fatty acid).

was higher compared to the other studies (D'Amico \& Donnelly, 2010 and Suguna et al., 2012) reporting the average SPC of $3.34 \log \mathrm{CFU} / \mathrm{mL}$ and $4.5 \log \mathrm{CFU} / \mathrm{mL}$, respectively.

However, the bacterial count did not significantly affect by diet supplementation, preferably by an external source like an airborne dust particle, unhygienic practices during milking, handling, and transporting milk (Delavenne et al., 2011; Verraes et al., 2014). Several others researcher also propose that dirty milking area or surrounding that permits bacterial contamination (Nordin et al., 2018), season and geographical location of farmhouse and many additional extrinsic factors (Suguna et al., 2012) result in unhygienic environment for milking purposes which prompting the high level of SPC value or bacterial contamination in milk.

\section{Fatty Acid Composition in Saanen Milk}

The non-significant effect of different groups in SFA and UFA might due to the same basal diet used in this study. The previous studies described that milk fatty acid could only be altered when there was additional oil supplemented or with high fat and low fiber diet (Chilliard \& Ferlay, 2004; Novotná et al., 2019; Silva et al., 2020). The SFA in control and CMB were slightly higher compared to previous research by Singh et al.
(2018) at 68.37\%, and UFA in both UMMB and MUMB was higher compared to previous researches (Singh et al., 2018) at $31.63 \%$. However, when compared to Zailan \& Yaakub, (2018), all treatments had a higher SFA value $(66 \%)$, while UFA was lower in all treatments (34\%). The differences in fatty acids proportions were influenced by lipid metabolism (Zailan \& Yaakub, 2018) and the composition of pasture (Singh et al., 2018).

Current findings showed that higher butyric acid (C4), palmitic acid (C16), heptadecanoic acid (C17), stearic acid (C18), palmitoleic acid (C16:1), oleic acid $(\mathrm{C} 18: 1 \mathrm{n} 9 \mathrm{c})$, linoleic acid (C18:2n6c) and eicosapentaenoic acid (C20:5n3) values (1.37\%, 21.58\%, 0.45\%, 8.58\%, $0.40 \%, 16.56 \%, 0.99 \%$ and $0.09 \%$ in fat, respectively) compared to the previous studies (Sumarmono et al., 2015; Strzałkowska et al., 2009). However, C6, C8, C10, $\mathrm{C} 12, \mathrm{C} 14$, myristoleic acid (C14:1), $\alpha$-Linolenic acid (C18:3n3), and eicosatrienoic acid (C20:3n3) showed lower fatty acid percentage (\% in fat) compared to the previous findings (Strzałkowska et al., 2009). Statements above were supported by the finding of Elgersma (2015), which described that increased intake of herbage or fresh grass could raise the PUFA content and reduce SFA content. Mira et al. (2018) stated that Napier grass intake was higher in UMMB and MUMB group, while $\mathrm{CMB}$ had a lower intake of Napier grass. The high content of SFA consumption is not healthy for humans 
as it will increase the risk of cardiometabolic disease such as cardiovascular and coronary heart disease. Consumption of high SFA also leads to the increase of cholesterol content and the risk of an incident of type 2 diabetes (Chalder, 2015).

\section{CONCLUSION}

Dietary supplementations of UMMB and MUMB assist in maintaining the performance of lactating does by improving the iron content and fatty acid concentration of milk.

\section{CONFLICT OF INTEREST}

We certify that there is no conflict of interest with any financial, personal, or other relationships with other people or organization related to the material discussed in the manuscript.

\section{ACKNOWLEDGEMENT}

This research was funded by the Universiti Malaysia Kelantan (UMK) under the Matching Research Grant UMK-Industry (R/SGJP/A0700/01083A/ 002/2019/00611). Our deepest gratitude to Mr. Mohd Nasaruddin bin Mohd Yusoff, the Managing Director of Yusof Ecofarm, Tanah Merah, Kelantan for providing the research facilities.

\section{REFERENCES}

Chalder, P. C. 2015. Functional roles of fatty acids and their effects on human health. JPEN 20: 1-15. https://doi. org/10.1177/0148607115595980

Chilliard, Y. \& A. Ferlay. 2004. Dietary lipids and forages interactions on cow and goat milk fatty acid composition and sensory properties. Reprod. Nutr. Dev. 44: 467-492. https:// doi.org/10.1051/rnd:2004052

Cupáková, S., M. Pospíšilová, R. Karpíšková, B. Janštová, \& L. Vorlová. 2012. Microbiological quality and safety of goat's milk from one farm. Acta Univ. Agric. Silvic. Mendel. Brun. LX(6): 33-38. https://doi.org/10.11118/actaun201260060033

Currò, S., C. L. Manuelian, M. De Marchi, P. De Palo, S. Claps, A. Maggiolino, \& G. Neglia. 2019. Autochthonous dairy goat breeds showed better milk quality than Saanen under the same environmental conditions. Arch. Anim. Breed. 62: 83-89. https://doi.org/10.5194/aab-62-83-2019

D'Amico, D. J. \& C. W. Donnelly. 2010. Microbiological quality of raw milk used for small-scale artisan cheese production in Vermont: Effect of farm characteristics and practices. J. Dairy Sci. 93: 134-147. https://doi.org/10.3168/jds.2009-2426

Dieffenbacher, A. \& W. D. Pocklinton. 1987. Standard Methods for the Analysis of Oils, Fats and Derivatives (7th ed). Blackwell Scientific Publications, London.

Delavenne, E., J. Mounier, K. Asmani, J. L. Jany, G. Barbier, \& G. Le Blay. 2011. Fungal diversity in cow, goat and ewe milk. Int. J. Food Microbiol. 151: 247-251. https://doi. org/10.1016/j.ijfoodmicro.2011.08.029

Department of Statistics, M. 2019. Quarterly Gross Domestic Product. Department of Statistics, Malaysia., 70.

Elgersma, A. 2015. Grazing increases the unsaturated fatty acid concentration of milk from grass-fed cows: A review of the contributing factors, challenges and future perspectives. Eur. J. Lipid Sci. Technol. 117: 1345-1369. https://doi. org/10.1002/ejlt.201400469
Gómez-Cortés, P., A.Cívico, M. A. De La Fuente, N. Núñez Sánchez, F. Peña Blanco, \& A. L. Martinez Marin. 2018. Effects of dietary concentrate composition and linseed oil supplementation on the milk fatty acid profile of goats. Animal 12: 2310-2317. https://doi.org/10.1017/ S1751731118000381

Idamokoro, E. M., V. Muchenje, \& P. J. Masika. 2017. Yield and milk composition at different stages of lactation from a small herd of Nguni, Boer, and non-descript goats raised in an extensive production system. Sustainability 9: 1000. https://doi.org/10.3390/su9061000

Idowu, T.S. \& O.O. Adewumi. 2017. Genetic and nongenetic factors affecting yield and milk composition in goats. J Adv. Dairy Res. 05: 2-5. https://doi. org/10.4172/2329-888X.1000175

Kanani, J., S. D. Lukefahr, \& R. L. Stanko. 2006. Evaluation of tropical forage legumes Medicago sativa, Dolichos lablab, Leucaena leucocephala and Desmanthus bicornutus) for growing goats. Small Rumin. Res. 65: 1-7. https://doi. org/10.1016/j.smallrumres.2005.04.028

Keles, G., F. Yildiz-Akgul, \& V. Kocaman. 2017. Performance and milk composition of dairy goats as affected by the dietary level of stoned olive cake silages. Asian-Australas. J. Anim. Sci. 30: 363-369. https://doi.org/10.5713/ajas.16.0482

Mengistu, G. \& W. Hassen. 2017. Review on : supplementary feeding of urea molasses multi-nutrient blocks to ruminant animals for improving productivity. IJVSAH 2: 43-49.

Mengistu, G. \& W. Hassen. 2018. Supplementary feeding of urea molasses multi- nutrient blocks to ruminant animals for improving productivity. Acad. Res. J. Agri. Sci. Res. 6: 52-61.

Min, B. R., S. P.Hart, T. Sahlu, \& L. D. Satter. 2005. The effect of diets on milk production and composition on lactation curves in pastured dairy goats. J. Dairy Sci. 88: 2604-2615. https://doi.org/10.3168/jds.S0022-0302(05)72937-4

Mira, P., M. Wan Zahari, N. D. Rusli, \& K. Mat. 2018. Effects of non-medicated and medicated urea molasses multinutrient blocks on dry matter intake, growth performance, body condition score and feed conversion ratio of Saanen lactating does fed conventional diets. Pertanika J. Trop. Agric. Sci. 41: 729-740.

Mubi, A.A., I.D. Mohammed, \& A. Kibon. 2013. Effects of multinutrient blocks supplementation on the performance of Yankasa sheep fed with basal diet of rice straw in the dry season of Guinea Savanna Region of Nigeria. Arch. Appl. Sci. Res. 5: 172-178.

Muralidharan, J., A. K. Thiruvenkadan, \& V. Ramesh Saravanakumar. 2016. Effect of concentrate and urea molasses mineral block (UMMB) supplementation on the growth and feed consumption of Mecheri lambs under intensive rearing. Indian J. Anim. Res. 50: 382-386. https:// doi.org/10.18805/ijar.9421

Nordin, Y., S. Y. Kwan, W. S. Chang, Y. Y. Loo, C. W. Tan, S. N. Mohd Fadzil, \& R. Son. 2018. Evaluation of bacteriological quality of locally produced raw and pasteurised milk in Selangor, Malaysia. Food Res. 3: 208-212. https://doi. org/10.26656/fr.2017.3(3).235

Novotná, K., M. Ptáček, M. Fantová, L. Nohejlová, L. Stádník, M. Okrouhlá, \& Z. Peták. 2019. Impact of concentrate level and stage of lactation on fatty acid composition in goat milk. Sci. Agric. Bohem. 50: 171-175. https://doi. org/10.2478/sab-2019-0023

Ramchurn, R. \& A. Ruggoo. 2000. Digestibility and growth in the domestic rabbit using multi- nutrient blocks as a feed supplement. Livest. Res. Rural. Dev. 12: 15-25.

Sazila, N. A. S. N., F. A. Abdullah, N. A. M. Khadri, S. Sidek, F. A. Abdullah, K. Mat, M. A. Ayob, \& M. M. Rahman. 2018. The Intention Level among Felda Youth to Re-Migrate from City for Livestock Entrepreneurship: A Preliminary 
Study. Int. J. Acad. Res. Bus. Soc. Sci. 8: 566-577. https://doi. org/10.6007/IJARBSS/v8-i6/4258

Silva, L. S., J. V. F. L. Cavalcanti, A. L. R. Magalhães, K. R. Santoro, G. D. Gonçalves, L. P. V. Santana, \& O. C. Almeida. 2020. Soybean oil modulates the fatty acid synthesis in the mammary gland, improving nutritional quality of the goat milk. Small Rumin. Res. 183. https://doi. org/10.1016/j.smallrumres.2019.106041

Singh, A., S. Nayak, R. P. S. Baghel, A. Khare, \& C. D. Malapure. 2018. Dietary manipulations to alter milk fat composition. J. Entomol. Zool. Stud. 6: 176-181.

Shahudin, M. S., A. A. A. Ghani, M. Zamri-Saad, A. B. Zuki, F. F. J. Abdullah, H. Wahid, \& H. A. Hassim. 2018. The necessity of a herd health management programme for dairy goat farms in Malaysia. Pertanika J. Trop. Agric. Sci. 41: $1-18$.

Skapetas B. \& V. Bampidis. 2016. Goat production in the world: present situation and trends. Livest. Res. Rural. Dev. 28: 200.

Strzałkowska N., A. Jóźwik, E. Bagnicka, J. Krzyżewski, K.Horbańczuk, B. Pyzel, \& J. O. Horbańczuk. 2009. Chemical composition, physical traits and fatty acid profile of goat milk as related to the stage of lactation. Anim. Sci. Pap. Rep. 27: 311-320
Suguna, M., B. Rejeev, \& W. Nadiah. 2012. Microbiological quality evaluation of goat milk collected from small- scale dairy farms in Penang Island, Malaysia. Int. Food Res. J. 19: 1241-1245.

Sumarmono, J., M. Sulistyowati, \& Soenarto. 2015. Fatty acids profiles of fresh milk, yogurt and concentrated yogurt from Peranakan Etawah goat milk. Procedia Food Sci. 3: 216-222. https://doi.org/10.1016/j.profoo.2015.01.024

Tufarelli, V., M. Dario, \& V. Laudadio. 2009. Forage to concentrate ratio in Jonica breed goats: Influence on lactation curve and milk composition. J. Dairy Sci. 76: 124-128. https://doi.org/10.1017/S0022029908003841

Verraes, C., W. Claeys, S. Cardoen, G. Daube, L. De Zutter, H. Imberechts, \& L. Herman. 2014. A review of the microbiological hazards of raw milk from animal species other than cows. Int. Dairy J. 39: 121-130. https://doi.org/10.1016/j. idairyj.2014.05.010

Zailan, M. Z. \& H. Yaakub. 2018. Milk composition and fatty acids profile at different stages of lactation in Jamnapari crossbred goats. Malays. J. Anim. Sci. 21: 109-122.

Zamberlin S., N. Antunac, J. Havranek, \& D. Samaržija. 2012. Mineral elements in milk and dairy products. Mljekarstvo 62:111-125. 